\title{
Determinan Ekspor Di Indonesia
}

\author{
Fanny Septina \\ Universitas Ciputra Surabaya, septinafanny@gmail.com
}

\begin{abstract}
ABSTRAK
Penelitian ini bertujuan untuk mengeksplorasi faktor makroekonomi yang mempengaruhi ekspor nonmigas di Indonesia. Data penelitian yaitu data ekspor nonmigas, Produk Domestik Bruto, inflasi, kurs US dolar, investasi asing langsung pada periode 2010-2019 yang dipublikasikan oleh statistik Bank Indonesia. Metode penelitian menggunakan analisis Vector Error Correction Model (VECM) dengan uji stasioner Augmented Dickey Fuller (ADF), uji kointegrasi Johansen, uji kausalitas Granger, Error Correction Model. Hasil penelitian menunjukkan terdapat hubungan kointegrasi antar semua variabel dependen dan independen, hubungan searah kurs US dolar dan inflasi terhadap Produk Domestik Bruto, Produk Domestik Bruto terhadap ekspor. Pada jangka pendek Produk Domestik Bruto, inflasi, kurs, dan investasi asing langsung tidak berpengaruh signifikan terhadap ekspor nonmigas. Pada jangka panjang, Produk Domestik Bruto berpengaruh signifikan terhadap ekspor nonmigas.

Kata Kunci : ekspor nonmigas, makroekonomi, kointegrasi, kausalitas, error correction model
\end{abstract}

\begin{abstract}
This study aims to explore macroeconomic factors that affect non-oil and gas exports in Indonesia. The research data are non-oil and gas export data, Gross Domestic Product, inflation, US dollar exchange rate, foreign direct investment in the 2010-2019 period published by Bank Indonesia statistics. The research method uses the Vector Error Correction Model (VECM) analysis with the Augmented Dickey Fuller (ADF) stationary test, Johansen's cointegration test, Granger causality test, Error Correction Model. The results showed there was a cointegration relationship between all dependent and independent variables, a direct relationship with the US dollar exchange rate and inflation on Gross Domestic Product, Gross Domestic Product on exports. In the short term Gross Domestic Product, inflation, exchange rates, and foreign direct investment have no significant effect on non-oil and gas exports. In the long run, Gross Domestic Product has a significant effect on non-oil and gas exports.

Keywords: non-oil export, macroeconomy, cointegration, causality, error correction model
\end{abstract}

Naskah diterima: 27-08-2020, direvisi: 01-07-2020, diterbitkan: 01-09-2020

\section{PENDAHULUAN}

Indonesia memiliki sumber daya alam dan sumber daya manusia yang potensi komoditas nonmigasnya berkembang luar biasa. Perubahan kondisi global baik secara sosial, teknologi, politik maupun ekonomi berdampak pada aktivitas industrial, ekspor dan impor di Indonesia. Terutama dalam sepuluh tahun terakhir periode 2010 hingga 2019, dimana nilai ekspor nonmigas sempat mengalami penurunan namun cenderung stabil, dibandingkan ekspor migas yang mengalami penurunan. Berdasarkan neraca perdagangan Indonesia periode 2015 hingga 2019 yang dirilis oleh Kementrian Perdagangan Republik Indonesia, tren pertumbuhan ekspor tahun 2015 hingga 2019 untuk ekspor migas sebesar $-5,33 \%$ dan ekspor non migas sebesar 5,55\%. Sumber daya energi semakin lama akan mengalami penurunan jumlah. Sektor non migas menjadi peluang pemerintah untuk meningkatkan pertumbuhan ekonomi.

Studi empiris yang dilakukan oleh beberapa peneliti tentang kajian makroekonomi, pertumbuhan ekonomi, ekspor, impor, 
menunjukkan bahwa adanya hubungan kointegrasi dan kausal antara Produk Domestik Bruto (PDB) terhadap ekspor maupun impor. Variabel makroekonomi lainnya seperti kurs, inflasi, suku bunga, investasi asing turut berpengaruh terhadap pertumbuhan ekonomi (PDB) dan eksporimpor. Rupiah yang melemah terhadap US dolar dinilai tidak menarik oleh investor asing yang ingin investasi pada proyek atau industri non migas di Indonesia. Kenaikan harga bahan baku lokal akan berdampak pada biaya produksi dan harga jual produk yang diekspor ke luar negeri. Demikian penelitian ini bertujuan untuk mengetahui hubungan antara faktor makroekonomi yaitu PDB, Inflasi, kurs dan investasi asing langsung dengan ekspor nonmigas di Indonesia, baik dalam jangka pendek dan jangka panjang.

\section{KAJIAN LITERATUR}

Performa ekspor dipengaruhi oleh determinan internal yang dapat dikontrol seperti strategi pemasaran ekspor, manajemen perilaku dan persepsi konsumen, dan dipengaruhi oleh determinan yang tidak terkontrol secara internal (karakteristik manajemen, karakteristik perusahaan dan kompetensi) atau eksternal (karakteristik industri, karakteristik pasar domestik dan luar negeri). Pada industri kecil dan menengah performa ekspor dipengaruhi oleh lingkungan tempat beroperasi dan juga karakteristik inheren perusahaan, sumber daya yang dimanfaatkan dan kompetensinya disesuaikan dengan strategi ekspor (Maurel, 2009).

Penelitian Huang et al (2008), intensitas ekspor diperoleh dari nilai ekspor dibagi nilai penjualan, dibutuhkan waktu untuk menunjukkan dampak dari pengurangan biaya, investasi pada penelitian dan pengembangan, inovasi produk, kompetisi industrial. Ada selisih waktu pada hubungan kausal antar variabel tersebut. Pada sebuah ekonomi yang dinamikanya cukup tinggi seperti Cina, kesuksesan perusahaan pada tahun tersebut merupakan dampak dari kompensasi strategi atau aktivitas penelitian dan pengembangan yang telah dipersiapkan sejak setahun atau dua tahun sebelumnya.
Dari situasi tersebut dapat diamati adanya time-lag antara intensitas ekspor dengan explanatory-variabel (Huang et al., 2008).

Penelitian yang dilakukan oleh Grandinetti dan Mason (2012) dengan sampel penelitian industri kecil dan menengah. Variabel penelitian yaitu komitmen perusahaan untuk mengembangkan strategi marketing internasional, struktur organisasi untuk ekspor, mode internasionalisasi (investasi asing langsung, aliansi internasional, globalsourcing), ukuran perusahaan, lamanya perusahaan didirikan, pengalaman internasional. Mode internasionalisasi signifikan postif dan berpengaruh langsung terhadap performa ekspor. Variabel strategi dan organisasional karakteristik perusahaan berpengaruh tidak langsung dan dimediasi oleh tiga determinan. Upaya perusahaan untuk mengembangkan strategi internasional dan struktur organisasi untuk ekspor secara umum berpengaruh positif terhadap performa ekspor (Grandinetti \& Mason, 2012).

Jika perusahaan lokal memproduksi dan menjual produknya ke luar negeri, maka ekspor dan investasi asing langsung tidak sesuai. Anak perusahaan berada di negara lain dan berfungsi untuk mendukung proses produksi, bukan ekspor murni. Jika memilih mengadopsi di negara tempat beroperasi, menggunakan perusahaan lokal untuk produksi maka yang terjadi adalah kegiatan ekspor murni dan investasi langsung atas ekspor tersebut. Perusahaan yang berinvestasi langsung di pasar luar negeri akan memperoleh informasi dan pengetahuan yang cukup untuk mengadopsi strategi marketing yang sesuai karakteristik tertentu di pasar ekspor. Tidak hanya itu, penjualan anak perusahaan ke pasar luar negeri memiliki peran penting untuk mendorong performa ekspor perusahaan induk (Grandinetti \& Mason, 2012).

Tingkat suku bunga pasar uang, harga saham, dan kredit konsumsi rumah tangga dengan pertumbuhan ekonomi saling mempengaruhi satu sama lain. Implikasinya, nilai sebelumnya dari suku bunga pasar uang, harga saham, dan kredit konsumsi rumah tangga dapat digunakan untuk memprediksi pertumbuhan ekonomi dan 
sebaliknya (Buhaerah, 2017). Tingkat pertumbuhan ekonomi mempengaruhi tingkat suku bunga pinjaman searah yang artinya nilai pertumbuhan ekonomi yang lalu dapat dilibatkan untuk mempredikasi tingkat suku bunga pinjaman.

Penelitian Abidin et al (2013) menggunakan uji Hausman membandingkan Fixed Effect Model, Random Effect Model dan Pooled Model, hasilnya disarankan menggunakan Fixed Effect Model untuk mengukur dampak ekspor Malaysia dengan negara anggota OIC (Organization of Islamic Cooperation). Model Gravity menunjukkan bahwa ekspor Malaysia dipengaruhi oleh faktor size of economy. Nilai PDB perkapita bernilai negatif, dampak economies of scale lebih dominan dibandingkan dampak penyerapan sebuah negara atas peningkatan PDB perkapita. Jika PDB perkapita meningkat, akan lebih banyak produksi barang dan kecenderungan impor akan menurun. koefisien kurs negatif, apresiasi terhadap kurs akan menurunkan ekspor. Arus ekspor antara Malaysia dengan negara anggota OIC dianalisis melalui faktor mayoritas seperti size of the economies, level of openness of the economy, inflasi dan kurs. Pembuat kebijakan memainkan peran penting untuk mengeksploitasi vast market seperti fokus pada area negara di benua Afrika serta akselerasi upaya untuk mewujudkan ICM (Abidin et al., 2013).

Bakari dan Mabrouki melakukan studi dengan data dari Turki menemukan adanya hubungan kausal antara impor dengan pertumbuhan ekonomi, ekspor dengan pertumbuhan ekonomi, namun hasil uji regresi berganda menunjukkan variabel ekspor dan impor tidak berpengaruh signifikan terhadap PDB (Bakari \& Mabrouki, 2017a). Studi yang sama diulang kembali dengan data berbeda yaitu dari Panama, hasilnya tidak ada hubungan kausal antara ekspor impor dengan PDB, uji regresi berganda menunjukkan ekspor dan import tidak berpengaruh signifikan terhadap PDB (Bakari \& Mabrouki, 2017b). Pada studi empiris yang melibatkan kelompok industri high-tech dan low-tech, kurs dan high-tech ekspor berpengaruh signifikan terhadap pertumbuhan ekonomi (PDB), sedangkan inflasi dan tingkat suku bunga tidak berpengaruh signifikan terhadap pertumbuhan ekonomi (PDB) (Chowdhury et al., 2019). Inflasi dan tingkat suku bunga tidak berpengaruh signifikan terhadap pertumbuhan ekonomi (PDB), money supply dan kurs berpengaruh signifikan terhadap pertumbuhan ekonomi (PDB). Pertumbuhan ekonomi didukung oleh kebijakan moneter yang efektif untuk mengontrol inflasi dan suku bunga (Ahmad et al., 2016). Pham \& Nguyen (2013) menggunakan variabel kurs bilateral, investasi asing langsung terhadap Vietnam dan ekspor di Vietnam dengan metode analisis kointegration dan fixed effects model untuk mengetahui hubungan antar variabel. Hasil penelitian menunjukkan uji statistik signifikan, depresiasi mata uang Dong Vietnam terhadap mata uang asing meningkatkan investasi asing langsung ke Vietnam dan ekspor Vietnam (Pham \& Nguyen, 2013).

Studi lainnya menemukan bahwa negara berkembang akan lebih baik ekonominya ketika ekspor produk high-tech dan impor produk low-tech. Investasi dan high-tech ekspor berpengaruh signifikan terhadap PDB sedangkan population, low-tech ekspor, low-tech impor tidak berpengaruh signifikan terhadap PDB (Kilavuz \& Topcu, 2012). Faktor yang mempengaruhi perusahaan di Indonesia untuk melakukan ekspor sangat beragam tergantung pada lingkungan industrinya (Dijk, 2002). Penelitian ini ingin menguji kembali secara empiris, faktor yang mempengaruhi ekspor non migas di Indonesia menggunakan model error correction, periode pengamatan sepuluh tahun terakhir dengan faktor makroekonomi yang berbeda dari penelitian terdahulu dengan obyek penelitian di Indonesia. Berdasarkan beberapa studi empiris di negara lain, pertumbuhan ekonomi (PDB), inflasi, kurs dan investasi asing langsung memiliki hubungan kointegrasi dan kausal dengan ekspor pada jangka panjang.

\section{METODE PENELITIAN}

Data yang digunakan yaitu data ekspor, PDB, inflasi dan kurs, investasi asing langsung, semua data tersebut disajikan dalam triwulan mulai periode 2010-2019, diunduh dari website resmi Bank Indonesia 
sebagai bank sentral Republik Indonesia. Studi empiris menggunakan analisis time-

series dengan persamaan regresi:
$\exp _{t}=\alpha+\beta_{1} G D P_{t}+\beta_{2} \operatorname{Inf} f_{t}+\beta_{3} E x R_{t}+\beta_{4} F D I_{t}{ }_{t}{ }_{t}=\alpha_{0}+\gamma Y_{t-1}+\beta_{i} \sum_{i=1}^{p} \Delta Y_{t-i}+\varepsilon_{t}$

Keterangan:

$\exp _{t}=$ ekspor periode $\mathrm{t}$

$G D P_{t}=$ Produk domestik bruto periode $\mathrm{t}$

$\operatorname{In} f_{t=\text { inflasi periode } \mathrm{t}}$

$E x R_{t}=$ kurs, nilai tukar rupiah terhadap US dolar periode $\mathrm{t}$

$F D I_{t}=$ Investasi asing langsung periode $\mathrm{t}$

Variabel dependen Y diproksikan oleh ekspor nonmigas. Variabel independen diproksikan oleh PDB (produk domestik bruto), tingkat inflasi, kurs (nilai tukar Rupiah terhadap mata uang asing US dolar) dan investasi asing langsung di proyek Indonesia.

\section{Hipotesis}

H1: Terdapat hubungan antara Produk Domestik Bruto dengan ekspor nonmigas pada jangka panjang.

$\mathrm{H} 2$ : Terdapat hubungan antara inflasi dengan ekspor nonmigas pada jangka panjang.

H3: Terdapat hubungan antara kurs rupiah terhadap US dolar dengan ekspor nonmigas pada jangka panjang.

H4: Terdapat hubungan antara investasi asing langsung dengan ekspor nonmigas pada jangka panjang.

\section{Tahapan Analisis}

Analisis vector autoregression pada dasarnya sejajar dengan model persamaan simultan, hanya bedanya pada persamaan simultan ada variabel endogen dan eksogen, dalam analisis ini semua variabel adalah variabel endogen (Novita et al., 2009). Setiap variabel penelitian diobservasi dan dipengaruhi oleh variabel lainnya di masa lampau.

\section{Unit Root Test:}

Data time-series variabel dependen dan independen dalam penelitian ini memiliki tren sehingga perlu dilakukan uji ADF (Augmented Dickey Fuller) dilakukan untuk mengetahui data stasioner. Hasilnya data stasioner pada uji unit root first difference. Persamaan ADF:

Keterangan:

$\Delta Y_{t}=$ model first difference

$\alpha_{0}=$ intercept

$Y_{t}=$ variabel yang diuji stasioner

$p=$ panjang lag yang digunakan dalam model

$\varepsilon=$ eror

\section{Penentuan Lag Optimal:}

Penelitian ini menggunakan beberapa kriteria informasi yang terdiri dari sequential modified LR test statistic (LR), Final Prediction Error (FPE), Akaike Information Criterion (AIC), Schwarz information Criterion (SIC) dan Hannan-Quinn Information Criterion (HQ) menunjukkan lag yang diajukan.

\section{Uji Engle-Granger:}

Metode yang digunakan untuk menganalisis hubungan kausalitas antar variabel yang diamati yaitu uji kausalitas Granger. Apabila kedua variabel yang diujikan pada penelitian ini tidak stasioner pada tingkat level, maka keduanya diindikasikan mengandung kointegrasi. Hal ini berarti ada hubungan atau kesetimbangan jangka panjang antara kedua variabel tersebut.

\section{Uji Johansen:}

Kointegrasi terjadi jika variabel independen dan variabel dependen sama-sama merupakan trend sehingga masing-masing tidak stasioner. Uji Johansen untuk mengetahui hubungan timbal balik variabel pada jangka panjang. Ada dua analisis yaitu trace test dan maximum eigen value test. Persamaan regresi kointegrasi:

$Y_{t}=\alpha+\beta_{1} X_{1}+\beta_{2} X_{2}+\beta_{3} X_{3}+\beta_{4} X_{4}+e_{t}$

Keterangan:

$\beta=$ long-run multiplier yang mengukur pengaruh jangka panjang variabel $\mathrm{x}$ dan $\mathrm{y}$.

\section{Error Correction Model:}

Kointegrasi antara dua variabel mengindikasikan ada hubungan atau 
kesetimbangan jangka panjang antara kedua variabel tersebut. Pada jangka pendek, jika terjadi fluktuasi perekonomian maka akan timbul ketidaksetimbangan (disequilibrium) antar variabel yang kointegrasi tersebut. Model yang memasukan penyesuaian untuk melakukan koreksi bagi ketidaksetimbangan ini adalah model koreksi kesalahan ECM (error correction model) untuk mendeteksi seberapa besar dan cepat penyesuaian jangka pendek antar variabel yang terkointegrasi menuju kondisi keseimbangan kembali. Justifikasi ECM digunakan untuk mengetahui data time-series memiliki tren atau kesetimbangan jangka panjang, penyesuaian dan koreksi terhadap kesetimbangan jangka panjang. Persamaan ECM:

$\Delta Y_{t}=\varphi+\lambda e_{t-1}+\omega_{0} \Delta X_{t}+\varepsilon_{t}$

Keterangan:

$\lambda e_{t-1}=\lambda_{<0} ; e_{t-1}$ adalah eror persamaan regresi variabel $\mathrm{y}$ dan $\mathrm{x}$

$\varepsilon_{t}=$ eror
Variabel $\Delta Y_{t}$ dan $\Delta X_{t}$ masing-masing telah stasioner artinya ada hubungan kointergrasi sehingga error equilibrium akan stasioner, variabel dependen dan semua variabel independen pada model ECM akan stasioner.

\section{PEMBAHASAN}

\section{Uji ADF (Augmented Dickey Fuller)}

Berdasarkan tabel hasil uji ADF (Augmented Dickey Fuller) data time-series pada penelitian ini stasioner atau tidak terdapat unit root pada diferensiasi pertama, nilai signifikansi probabiliti semua variabel lebih kecil dari 0,05. Sedangkan lag optimum yang digunakan adalah Lag-2 karena signifikansi kriteria seleksi di LR, FPE dan AIC.

Tabel 1. Hasil Uji ADF First Difference

\begin{tabular}{|l|l|l|}
\hline Variabel & Probabiliti & Keterangan \\
\hline Export & $0,0001^{*}$ & Stasioner pada diferensi 1 \\
\hline GDP & $0,0000^{*}$ & Stasioner pada diferensi 1 \\
\hline Inflation & $0,0004^{*}$ & Stasioner pada diferensi 1 \\
\hline Exchange Rate & $0,0151^{*}$ & Stasioner pada diferensi 1 \\
\hline FDI & $0,0003^{*}$ & Stasioner pada diferensi 1 \\
\hline
\end{tabular}

Ket.: (*)Signifikansi $<0,05$

Tabel 2. Hasil Uji Lag Optimum

\begin{tabular}{|l|l|l|l|l|l|l|}
\hline Lag & LogL & LR & FPE & AIC & SC & HQ \\
\hline $\mathbf{0}$ & 96,63174 & NA & $4,86 \mathrm{e}-09$ & $-4,953067$ & $-4,735375$ & $-4,876320$ \\
\hline $\mathbf{1}$ & 204,2222 & 180,2867 & $5,68 \mathrm{e}-11$ & $-9,417417$ & $-8,111267^{*}$ & $-8,956938^{*}$ \\
\hline $\mathbf{2}$ & 231,1154 & $37,79589^{*}$ & $5,54 \mathrm{e}-11^{*}$ & $-9,519753^{*}$ & $-7,125145$ & $-8,675542$ \\
\hline $\mathbf{3}$ & 251,5439 & 23,18907 & $8,77 \mathrm{e}-11$ & $-9,272643$ & $-5,789577$ & $-8,044699$ \\
\hline
\end{tabular}

Ket.: (*) signifikansi lag optimum sesuai kriteria

Tabel 3. Hasil Uji Kausalitas Granger

\begin{tabular}{|l|l|l|}
\hline Hipotesis & Probabiliti & Keterangan \\
\hline Log_Export $\rightarrow$ Log_Exchange Rate & 0,5906 & Tidak signifikan \\
\hline Log_Exchange Rate $\rightarrow$ Log_Export & 0,4313 & Tidak signifikan \\
\hline Log_FDI $\rightarrow$ Log Exchange Rate & 0,8726 & Tidak signifikan \\
\hline Log_Exchange Rate $\rightarrow$ Log_FDI & 0,5703 & Tidak signifikan \\
\hline Log_GDP $\rightarrow$ Log Exchange Rate & 0,3247 & Tidak signifikan \\
\hline Log_Exchange Rate $\rightarrow$ Log_GDP & $0,000006^{*}$ & Signifikan \\
\hline Log_Inflation $\rightarrow$ Log_Exchange Rate & 0,5449 & Tidak signifikan \\
\hline Log_Exchange Rate $\rightarrow$ Log_Inflation & 0,1662 & Tidak signifikan \\
\hline
\end{tabular}




\begin{tabular}{|l|l|l|}
\hline Log_FDI $\rightarrow$ Log_Export & 0,9451 & Tidak signifikan \\
\hline Log_Export $\rightarrow$ Log_FDI & 0,4116 & Tidak signifikan \\
\hline Log_GDP $\rightarrow$ Log_Export & $0,0541^{* *}$ & Signifikan \\
\hline Log_Export $\rightarrow$ Log_GDP & 0,8223 & Tidak signifikan \\
\hline Log_Inflation $\rightarrow$ Log Export & 0,1386 & Tidak signifikan \\
\hline Log_Export $\rightarrow$ Log_Inflation & 0,7389 & Tidak signifikan \\
\hline Log_GDP $\rightarrow$ Log_FDI & 0,8589 & Tidak signifikan \\
\hline Log_FDI $\rightarrow$ Log_GDP & 0,8971 & Tidak signifikan \\
\hline Log_Inflation $\rightarrow$ Log_FDI & 0,6580 & Tidak signifikan \\
\hline Log_FDI $\rightarrow$ Log_Inflation & 0,8899 & Tidak signifikan \\
\hline Log_Inflation $\rightarrow$ Log_GDP & $0,0242^{*}$ & Signifikan \\
\hline Log_GDP $\rightarrow$ Log_Inflation & 0,2907 & Tidak signifikan \\
\hline
\end{tabular}

Ket.: (*)Signifikansi $<0,05 ;(* *)$ Signifikansi $<0,1$

Tabel 4. Hasil Uji Kointegrasi Johansen - Trace Test

\begin{tabular}{|l|l|l|l|l|}
\hline Hipotesis & Eigen value & Trace statistic & Critical value & $\begin{array}{l}\text { MacKinnon's p- } \\
\text { values } \\
\text { Probabiliti }\end{array}$ \\
\hline None & 0,617196 & $71,73258^{*}$ & $69,81889^{*}$ & $0,0349^{*}$ \\
\hline At most 1 & 0,358124 & 36,20395 & 47,85613 & 0,3862 \\
\hline At most 2 & 0,271040 & 19,79962 & 29,79707 & 0,4365 \\
\hline At most 3 & 0,127003 & 8,102574 & 15,49471 & 0,4545 \\
\hline At most 4 & 0,079801 & 3,077105 & 3,841465 & 0,0794 \\
\hline
\end{tabular}

Ket.: (*) Signifikansi probabiliti < 0,05; Trace statistic > Critical value

Tabel 5. Hasil Uji Kointegrasi Johansen - Maximum Eigenvalue Test

\begin{tabular}{|l|l|l|l|l|}
\hline Hipotesis & Eigen value & Trace statistic & Critical value & $\begin{array}{l}\text { MacKinnon's p- } \\
\text { values } \\
\text { Probabiliti }\end{array}$ \\
\hline None & 0,617196 & $35,52863^{*}$ & $33,87687^{*}$ & $0,0315^{*}$ \\
\hline At most 1 & 0,358124 & 16,40433 & 27,58434 & 0,6313 \\
\hline At most 2 & 0,271040 & 11,69705 & 21,13162 & 0,5778 \\
\hline At most 3 & 0,127003 & 5,025469 & 14,26460 & 0,7386 \\
\hline At most 4 & 0,079801 & 3,077105 & 3,841465 & 0,0794 \\
\hline
\end{tabular}

Ket.: (*) Signifikansi probabiliti $<0,05$; Trace statistic $>$ Critical value

Tabel 6. Regresi Error Correction Model - Jangka Panjang

\begin{tabular}{|l|l|l|}
\hline Variabel & Probabiliti & Keterangan \\
\hline Konstanta & 0,0492 & - \\
\hline Log_GDP & $0,0011^{*}$ & Signifikan, H1 diterima \\
\hline Log_Inflation & 0,6044 & Tidak signifikan, H2 ditolak \\
\hline Log_Exchange Rate & 0,4457 & Tidak signifikan, H3 ditolak \\
\hline Log_FDI & 0,9141 & Tidak signifikan, H4 ditolak \\
\hline
\end{tabular}

Ket.: $\left(^{*}\right)$ Signifikansi $<0,05$

Tabel 7. Regresi Error Correction Model - Jangka Pendek

\begin{tabular}{|l|l|l|}
\hline Variabel & Probabiliti & Keterangan \\
\hline Konstanta & 0,9433 & - \\
\hline D(Log_GDP) & 0,6419 & Tidak signifikan, H1 ditolak \\
\hline D(Log_Inflation) & 0,6311 & Tidak signifikan, H2 ditolak \\
\hline \hline
\end{tabular}

ISSN: 2355-0295, e-ISSN: 2549-8932

http://ejournal.bsi.ac.id/ejurnal/index.php/ecodemica 


\begin{tabular}{|l|l|l|}
\hline D(Log_Exchange Rate) & 0,3844 & Tidak signifikan, H3 ditolak \\
\hline D(Log_FDI) & 0,7618 & Tidak signifikan, H4 ditolak \\
\hline EC (error correction) & $0,0000^{*}$ & Signifikan \\
\hline
\end{tabular}

Ket.: (*) Sigifikansi $<0,05$

\section{Uji Engle-Granger}

Hasil uji Engle-Granger dua langkah menghasilkan nilai signifikansi probabiliti $0,0042<0,05$ menunjukkan bahwa ada kointegrasi antar variabel. Kemudian dilanjutkan uji kausalitas Granger untuk mengetahui signifikansi pengaruh setiap variabel dengan variabel yang lain. Berdasarkan tabel, pada signifikansi 5\% yaitu Kurs dan inflasi berpengaruh signifikan terhadap Produk domestik bruto. Sedangkan pada signifikansi $10 \%$ yaitu variabel produk domestik bruto berpengaruh terhadap ekspor.

Pada signifikansi $<0,05$, hasil uji kausalitas Granger menunjukkan semua variabel independen tidak memiliki hubungan dua arah dengan variabel dependen ekspor. Namun ada variabel yang memiliki hubungan searah yaitu kurs terhadap produk domestik bruto, apresiasi atau depresiasi mata uang rupiah terhadap US dolar akan meningkatkan atau menurunkan nilai produk domestik bruto di Indonesia. Inflasi berhubungan searah terhadap produk domestik bruto, meningkatnya inflasi menyebabkan produk domestik bruto semakin tinggi, inflasi yang meningkat dapat dimaknai sebagai pertumbuhan ekonomi dan tingkat konsumsi yang cukup tinggi.

\section{Uji Johansen}

Berdasarkan tabel uji Johansen menunjukkan adanya kointegrasi antar variabel yaitu pertama, trace test, nilai trace statistic lebih besar dibandingkan critical value $71,73258>69,81889$, dengan $p$-value $0,0349<0,05$. Kedua, maximum eigenvalue test menunjukkan nilai trace statistic lebih besar dibandingkan crtitical value yaitu $35,52863>33,87687$, dengan $p$-value $0,0315<0,05$.

\section{Error Correction Model}

Persamaan regresi periode jangka panjang: $\exp _{t}=\alpha+\beta_{1} G D P_{t}+\beta_{2} \operatorname{Inf} f_{t}+\beta_{3} E x R_{t}+\beta_{4} F D I$

$$
\begin{gathered}
\exp _{t}=4.046069+0.604908 G D P_{t}-0.011614 \operatorname{Inf}_{t}-0.071 \\
+\varepsilon
\end{gathered}
$$

Pada jangka panjang, secara simultan variabel independen berpengaruh signifikan terhadap variabel dependen ekspor, nilai Probabiliti $F$-statistic 0,010650, signifikansi $<0,05$. Berdasarkan tabel, variabel PDB berpengaruh signifikan terhadap ekspor. Variabel inflasi, Kurs, dan investasi asing langsung tidak berpengaruh signifikan terhadap ekspor. Peningkatan nilai ekspor akan meningkatkan nilai PDB, namun sebaliknya akan menurunkan tingkat inflasi, nilai tukar rupiah terhadap US dolar mengalami apresiasi dan menurunkan investasi asing.

Persamaan regresi periode jangka pendek:

$\Delta \exp _{t}=\beta_{0}+\beta_{1} \Delta G D P_{t}+\beta_{2} \Delta \operatorname{Inf} f_{t}+\beta_{3} \Delta E x R_{t}+\beta_{4} \Delta F D I_{4}+\beta_{5} E$ $\Delta \exp _{t}=0.000522+0.145245 \Delta G D P_{t}-0.006487 \Delta I n f_{t}+0.513755 \Delta E x$

$$
+\varepsilon_{t}
$$

Pada jangka pendek, secara simultan semua variabel independen berpengaruh signifikan terhadap variabel dependen ekspor, nilai Probability F-statistic 0,000447, signifikansi $<0,05$. Variabel PDB, inflasi, kurs dan investasi asing langsung tidak berpengaruh signifikan terhadap ekspor. Koefisien kesalahan kesetimbangan (EC) signifikan, artinya pertumbuhan ekonomi jangka pendek menyesuaikan perubahan semua variabel penelitian ini, penyesuaian satu periode menuju kesetimbangan jangka panjang, dengan nilai signifikansi sebesar 0,8167 atau $-81,67 \%$. Peningkatan ekspor akan meningkatkan nilai PDB dan nilai tukar rupiah terhadap US dolar pada posisi depresiasi sedangkan inflasi akan menurun dan investasi asing menurun.

Hasil penelitian berdasarkan uji EngleGranger dua arah dan uji Johansen, semua variabel yaitu ekspor, PDB, inflasi dan investasi asing memiliki hubungan ${ }_{{ }_{k}}{ }_{k}$ iñ̂tegrasi. Sependapat dengan penelitian Medina-Smith (2001) antar variabel 
memiliki hubungan kointegrasi dan memiliki tren linier yang sama pada periode jangka panjang. Uji kausalitas Granger, variabel yang memiliki hubungan satu arah yaitu kurs dan inflasi terhadap Produk domestik bruto serta PDB terhadap ekspor. Adanya hubungan kausal antara ekspor growth dan real PDB pada jangka pendek maupun jangka panjang (Taban \& Aktar, 2008).

Inflasi menyebabkan PDB, peningkatan harga produk dan harga input produksi, diikuti dengan peningkatan pendapatan per kapita dan konsumsi rumah tangga berdampak pada pertumbuhan ekonomi di Indonesia. PDB menyebabkan ekspor, pertumbuhan ekonomi mampu menstimulus aktivitas ekspor di Indonesia. Berbeda dengan hasil penelitian Batubara \& Saskara (2013) menemukan PDB tidak menyebabkan ekspor, Indonesia belum memaksimalkan potensi input yang dimiliki untuk produksi sehingga produktivitas nasional belum bertumbuh sesuai ekspektasi. Ekspor dan PDB berpengaruh secara tidak langsung melalui impor terhadap utang luar negeri. Peningkatan nilai ekspor dan PDB menyebabkan peningkatan nilai impor dan berdampak pada bertambahnya utang luar negeri di Indonesia (Batubara \& Saskara, 2013). Sedangkan di Cina, terdapat hubungan jangka pendek dan signifikan negatif pada jangka panjang antara pertumbuhan ekonomi dan inflasi serta hubungan kausal tidak langsung pertumbuhan ekonomi terhadap inflasi. Negara dengan karakteristik pertumbuhan ekonomi dan makroekonomi yang stabil tidak akan mengalami dampak inflasi pada pertumbuhan ekonominya (Jayathileke \& Rathnayake, 2013). Teori persamaan standard gravity mengemukakan arus ekspor bilateral secara positif ditentukan oleh size of economy dan secara negatif di tentukan oleh bilateral distance. Kapasitas pasokan domestik dan permintaan potensial dari partner countries serta pasar berpengaruh signifikan positif terhadap arus ekspor di Pakistan, sementara bilateral distance menunjukkan signifikan negatif (Abbas \& Waheed, 2015).
Model VECM mengkonfirmasi pada jangka pendek, semua variabel independen yaitu PDB, inflasi dan investasi asing tidak berpengaruh signifikan terhadap variabel dependen ekspor. Pada jangka panjang, produk domestik bruto berpengaruh signifikan terhadap ekspor. Potensi sumber daya alam, sumber daya manusia Indonesia yang kreatif serta budaya tradisional yang unik selalu menarik perhatian konsumen pasar global akan produk-produk buatan Indonesia. Bahkan produk sektor industri kreatif menjadi salah satu produk unik yang selalu diekspor ke negara tujuan utama Amerika Serikat (Badan Ekonomi Kreatif, 2019). Berbeda dengan Medina-Smith (2001) populasi, investasi dan kapital berpengaruh signifikan positif terhadap ekspor, sedangkan PDB tidak berpengaruh signifikan terhadap ekspor. Namun terdapat hubungan jangka panjang antara PDB, investasi, populasi dan ekspor (MedinaSmith, 2001). Pada model dengan variasi variabel seperti ekspor, kapital, tenaga kerja, inflasi dan kredit berpengaruh signifikan terhadap PDB (Fatemah \& Qayyum, 2018). Studi yang dilakukan oleh Yee et al. (2016) menggunakan empat determinan yaitu impor, inflasi, investasi asing langsung, dan kurs. Implikasi pertama menunjukkan bahwa beberapa produk impor akan diekspor kembali setelah diberikan nilai tambah di Malaysia. Ketika inflasi berdampak pada ekonomi pasar hal ini mengindikasikan bahwa harga produk dan input produksi akan meningkat. Peningkatan harga produk dan input produksi akan mendorong peningkatan biaya produksi. Pengawasan investasi asing langsung diperlukan untuk memastikan bahwa investasi akan mengalir ke sektor keuangan dan manufaktur, kemudian membantu menstimulasi ekspor dan meningkatkan daya saing ekspor. Jika kurs domestik depresiasi berarti mengalami devaluasi. Hal ini disebabkan oleh harga produk luar negeri lebih tinggi dibandingkan harga produk nasional. Ini akan menstimulasi ekspor dan mendorong dampak positif kuantitas di neraca perdagangan. Harga produk lokal yang lebih rendah akan membuat konsumen luar negeri memilih untuk membeli lebih banyak 
produk lokal dibandingkan produk ekspor (Yee et al., 2016).

Ekspor dan kurs memiliki hubungan kointegrasi dan tidak memiliki hubungan kausalitas, kurs berpengaruh tidak signifikan terhadap ekspor. Fluktuasi rupiah terhadap US dolar tidak menyebabkan ekspor dan sebaliknya, serta apresiasi rupiah terhadap US dolar tidak berdampak si gnifikan terhadap penurunan ekspor di Indonesia. Sedangkan di Cina, implikasi apresiasi mata uang Cina terhadap US dolar signifikan menurunkan ekspor Cina ke Amerika. Penurunan ekspor bersifat substansial misalnya reform (apresiasi kurs) menyebabkan ekspor Cina ke Amerika menurun signifikan. Reform membuat impor ke Cina lebih murah kemudian mempengaruhi produksi dan perilaku eksportir Cina (misal, penggunaan impor input setengah jadi dan peningkatan kompetisi domestik dengan mengimpor produk akhir) (Liu et al., 2014).

investasi asing langsung tidak berpengaruh signifikan terhadap ekspor. Ekspor dan investasi asing langsung memiliki hubungan kointegrasi dan tidak memiliki hubungan kausalitas, investor asing tertarik berinvestasi pada proyek Indonesia, bukan karena potensi ekspor Indonesia. Investasi asing pada proyek di Indonesia tidak menjadi stimulus pendorong aktivitas ekspor. Studi dengan variabel yang sama menunjukkan bahwa investasi asing langsung tidak berpengaruh signifikan terhadap ekspor, sedangkan PDB, pertumbuhan PDB, kurs, sarana telekomunikasi (televisi dan telepon), labour force, savings, economic value added berpengaruh signifikan terhadap ekspor (Majeed \& Ahmad, 2006).

Penelitian serupa yang dilakukan Pham \& Nguyen (2013), menunjukkan hasil yang berbeda, investasi asing langsung Vietnam berhubungan erat dengan peningkatan ekspor dari Vietnam ke negara sumber investasi asing langsung. Ekspor Vietnam ke negara tertentu tidak hanya didukung oleh negara yg investasi asing langsung ke Vietnam namun juga negara-negara lain. Pertumbuhan ekspor Vietnam menarik perhatian untuk investasi asing langsung ke Vietnam (Pham \& Nguyen, 2013). Dualisme ekspor dan investasi asing langsung seperti saling berlawanan dan alternatif mode internalisasi, dapat diakses oleh perusahaan kecil hingga perusahaan multinasional. Komitmen pasar luar negeri melalui investasi langsung dan aktivitas ekspor tidak sesuai jika terdapat dua kondisi berikut; perusahaan lokal memproduksi dan menjual produknya ke luar negeri, pilihan ini diadopsi hampir semua pasar luar negeri dimana perusahaan tersebut beroperasi (Grandinetti \& Mason, 2012).

\section{PENUTUP}

Analisis data menggunakan VECM dilakukan secara bertahap. Uji ADF menunjukkan data stasioner pada diferensiasi pertama dan lag optimum yang digunakan lag-2. Uji Engle-Granger dua tahap dan uji Johansen menyatakan semua variabel (ekspor, PDB, inflasi, kurs dan investasi asing langsung) memiliki hubungan kointegrasi. Pada uji kausalitas Granger, variabel yang memiliki hubungan searah yaitu kurs dan inflasi terhadap produk domestik bruto serta PDB terhadap ekspor. Apresiasi rupiah terhadap US dolar menyebabkan pertumbuhan ekonomi, investor asing tertarik untuk berinvestasi pada proyek di Indonesia. Kenaikan harga produk atau harga input produksi diikuti peningkatan pendapatan per kapita dan konsumsi rumah tangga dampaknya terjadi pertumbuhan ekonomi. Model ECM mengkonfirmasi pertumbuhan ekonomi jangka pendek menyesuaikan perubahan semua variabel penelitian ini. Pada jangka pendek, semua variabel independen (PDB, inflasi, kurs dan investasi asing langsung) tidak berpengaruh signifikan terhadap variabel dependen ekspor. Pada jangka panjang, hanya variabel PDB yang berpengaruh signifikan positif terhadap ekspor. Pertumbuhan ekonomi mampu menjadi stimulus aktivitas ekspor di Indonesia terutama dalam jangka panjang. Potensi sumber daya alam, budaya tradisional dan kreatifitas menarik perhatian pasar global akan produk-produk buatan Indonesia. Kebijakan pemerintah yang berkaitan dengan ekspor non migas diharapkan dapat mempermudah pelaku usaha terutama usaha mikro kecil dan 
menengah (UMKM). Program pendampingan pengusaha kecil dan bantuan modal dinilai cukup membantu para pelaku usaha UMKM sektor kreatif. Sektor kreatif menjadi salah satu sektor yang berpeluang tumbuh cukup pesat, seperti industri game yang didukung kemajuan teknologi, produk tradisional kriya berupa kerajinan tangan yang banyak disukai oleh konsumen luar negeri seperti Amerika Serikat.

Penelitian selanjutnya dapat menambahkan variabel impor dan menggunakan rentang periode pengamatan lebih dari sepuluh tahun untuk mengamati dampak jangka panjang ekspor impor terhadap pertumbuhan ekonomi di Indonesia.

\section{REFERENSI}

Abbas, S., \& Waheed, A. (2015). Pakistan, S Potential Export Flow: The Journal of Developing Areas, 49(4), 367-378. https://doi.org/10.1353/jda.2015.0135

Abidin, I. S. Z., Bakar, N. A., \& Sahlan, R. (2013). The Determinants of Exports between Malaysia and the OIC Member Countries: A Gravity Model Approach. Procedia Economics and Finance, 5(13), 12-19. https://doi.org/10.1016/s22125671(13)00004-x

Ahmad, D., Afzal, M., \& Ghani, U. (2016). Impact of Exports on Economic Growth Empirical Evidence of Pakistan Impact of Monetary Policy on Economic Growth Empirical Evidence of Pakistan Faculty Department of Economics. International Journal of Applied Economic Studies, 4(6).

Badan Ekonomi Kreatif. (2019). Opus: Ekonomi Kreatif Outlook 2019. Badan Ekonomi Kreatif, 23-24.

Bakari, S., \& Mabrouki, M. (2017a). Impact of Exports and Imports on Economic Growth: New Evidence From Panama. Journal of Smart Economic Growth, 2(1), 67-79.

Bakari, S., \& Mabrouki, M. (2017b). The Relationship among Exports , Imports and Economic Growth in Turkey The Relationship among Exports, Imports and Economic Growth in Turkey. Munich Personal RePEc Archive, 76044.

Bank Indonesia. Data Statistik. Diunduh 3 Januari 2020 di https://www.bi.go.id/id/statistik/seki/te rkini/riil/Contents/Default.aspx

Batubara, D. M. H., \& Saskara, I. A. N. (2013). Analisis Hubungan Ekspor , Impor , PDB , Causality And CoIntegration Analysis Between Exports, Imports ,. Jurnal Ekonomi Kuantitatif Terapan, 8(1), 46-55.

Buhaerah, P. (2017). Pembangunan Keuangan dan Pertumbuhan Ekonomi : Studi Kasus Indonesia. Kajian Ekonomi \& Keuangan, 1(2). http://fiskal.kemenkeu.go.id/ejournal

Chowdhury, A. H. M. Y., Hamid, M. K., \& Akhi, R. A. (2019). Impact of Macroeconomic Variables on Economic Growth: Bangladesh Perspective. Information Management and Computer Science, 2(2), 19-22. https://doi.org/10.26480/imcs.02.2019. 19.22

Dijk, M. Van. (2002). The Determinants of Export Performance in Developing Countries: The Case of Indonesian Manufacturing The Determinants of Export Performance in Developing Countries: The Case of Indonesian Manufacturing Michiel van Dijk Eindhoven Centre for Innovation St. Technology Management, February.

Fatemah, A., \& Qayyum, A. (2018). Modeling the Impact of Exports on the Economic Growth of Pakistan. Munich Personal RePEc Archive, 83929, 21. https://doi.org/10.1453/ter.v5i1.1584

Grandinetti, R., \& Mason, M. C. (2012). Internationalization modes other than exporting: The missing determinant of export performance. European Business Review, 24(3), 236-254. 
https://doi.org/10.1108/095553412112 22495

Huang, C., Zhang, M., Zhao, Y., \& Varum, C. A. (2008). Determinants of exports in China: A microeconometric analysis. European Journal of Development Research, 20(2), 299317.

https://doi.org/10.1080/095788108020 60793

Jayathileke, P. M. B., \& Rathnayake, R. M. K. T. (2013). Testing the Link between Inflation and Economic Growth: Evidence from Asia. Modern Economy, 04(02), 87-92. https://doi.org/10.4236/me.2013.42011

Kementrian Perdagangan Republik Indonesia. Ekspor dan Impor Indonesia. Diunduh 1 Juli 2020 di https://statistik.kemendag.go.id/indone sia-export-import

Kilavuz, E., \& Topcu, B. A. (2012). Export and Economic Growth in the Case of the Manufacturing Industry: Panel Data Analysis of Developing Countries. International Journal of Economics and Financial Issues, 2(2), 201-215.

https://doi.org/10.25103/ijbesar.113.05

Liu, Q., Lu, Y., \& Zhou, Y. (2014). Do Exports Respond to Exchange Rate Changes? Inference from China's Exchange Rate Reform. Working Paper.

Majeed, M. T., \& Ahmad, E. (2006). Determinants of exports in developing countries. Pakistan Development Review, 45(4), 1265-1276. https://doi.org/10.30541/v45i4iipp.126 5-1276

Maurel, C. (2009). Determinants of export performance in French wine SMEs. International Journal of Wine Business Research, 21(2), 118-142. https://doi.org/10.1108/175110609109 67971
Medina-Smith, E. J. (2001). Is the export-led growth hypothesis valid for developing countries? A case study of Costa Rica. In Policy Issues in International Trade and Commodities (Issue 7).

Novita, M., Setiawan, A., \& Nugroho, D. B. (2009). Studi Kausalitas Granger Antara Nilai Tukar Rupiah Terhadap USD dan AUD menggunakan Analisis VAR. 1, 109-116.

Pham, T. H. H., \& Nguyen, T. D. (2013). Foreign Direct Investment, Exports and Real Exchange Rate Linkages in Vietnam: Evidence from a CoIntegration Approach. Southeast Asian Economies, $30(3), \quad 250$. https://doi.org/10.1355/ae30-3b

Taban, S., \& Aktar, I. (2008). an Empirical Examination of the Export-Led Growth Hypothesis in Turkey. Journal of Yaşar University, 3(11), 1535-1551. https://doi.org/10.19168/jyu.08658

Yee, L. S., WaiMun, H., Zhengyi, T., Ying, L. J., \& Xin, K. K. (2016). Determinants of Export: Empirical Study in Malaysia. Journal of International Business and Economics, 4(1), 61-75. https://doi.org/10.15640/jibe.v4n1a6

\section{BIODATA PENULIS}

Fanny Septina, S.E., M.M. Latar belakang pendidikan; S1-Akuntansi dan S2-Magister Manajemen bidang keuangan Universitas Katolik Widya Mandala Surabaya. Bidang penelitian; manajemen keuangan, akuntansi keuangan, makroekonomi, mikroekonomi, investasi dan pasar saham, green finance, green banking. Penghargaan dalam bidang penelitian; bersama tim memperoleh hibah Demand Driven Research Grant Oceanografi LIPI tahun 2018. 